\title{
ASSESSMENT OF MENTAL WORKLOAD OF FLIGHT ATTENDANTS BASED ON FLIGHT DURATION: AN EFFORT TO PROVIDE SAFE WORKING CONDITION
}

\author{
Ari WIDYANTI (1) *, Maisarah FIRDAUS \\ Department of Industrial Engineering, Bandung Institute of Technology, Bandung, Indonesia
}

Received 23 November 2018; accepted 18 December 2019

\begin{abstract}
Flight attendants play a crucial role in the service of the airline industry. The aim of this present study is to examine the mental workload of flight attendants, and it possible relation to the flight duration. Two hundred and one Indonesian flight attendants participate voluntarily in this study by filling out a mental workload questionnaire, the NASA-TLX questionnaire, in the end of their flight schedule. Results show that the mental workload of flight attendants regardless the flight duration is on a range of medium mental workload. Based on flight duration, the optimal mental workload is for 1-2 hours of flight. Implications of the result are discussed.
\end{abstract}

Keywords: mental, workload, flight attendants, flight duration, the NASA-TLX.

\section{Introduction}

Flight attendants play a crucial role in the service of the airline industry. In fact, flight attendants' in-flight service is the most direct and crucial airline service to customers. This is because passengers tend to evaluate airlines based on their degree of satisfaction with the in-flight service (Park, Robertson, \& Wu, 2004). Factors influence service quality of flight attendants can be divided into personal factors and operational factors (Ratanakomut \& Kitcharoen, 2013). Personal factors include personality, language proficiency, attitude, health, and income/benefits. Whereas operational factors include workloads, working environment, equipment and machine, training, company policy, and quality control (Mellert et al., 2008).

Over the last 20 years, research has been concerned with operational factors that might affect flight attendants' health such as irregular work schedules, lifting and handling of heavy objects, and workload (Damos, Boyett, \& Gibbs, 2013; Nagda \& Koonts, 2003; Griffiths \& Powell, 2012). Nyberg and Lennernäs (2017) and Hsu and Liu (2012) also found that flight attendants are confronted with demanding situations such as a long hour and overload. The implications of operational factors have been observed as well, such as stress (see Yeh, 2012; Karatepe \& Talebzadeh, 2016; Chen \& Kao, 2011 for examples), various health problems (e.g., sleep disorders, dermatology and eye problem due to cabin air quality, high exposure to contagious diseases, and of being injured; Lee et al., 2006).

In particular related to flight attendants' workload (defined as difference between demand of the task and capacity available in worker, Gopher \& Donchin, 1986), it is important to provide optimal workload since under load leads to boredom and long-term heavy workload can affect an employee's physical or mental health, performance, or productivity including service quality, accidents or illness (see Chen et al., 2010; Davidson, Guilding, \& Timo, 2006 for examples). However, as far as acknowledged by authors, only a limited study has been concerned with identifying the activities a flight attendant performs as well as the workload.

Most research in the context or workload of the flight attendants fall into categories of physical and psychosocial workload. In the context of physical workload, for example, Lee et al. (2006) reviewed physically strenuous activities of flight attendants that are handling carry-on baggage, handling carts (beverage, meal, and duty-free), service to passengers, and safety checks. Other research has also reported physical workload and musculoskeletal disorder (defined as disorders of the nerve, tendons, muscles, and supporting tissues that result from or are made worse by work conditions; Cohen et al., 1997) among flight attendants. In particular, the body region of flight attendants that most affected by musculoskeletal

*Corresponding author. E-mail: widyanti@mail.ti.itb.ac.id 
symptoms or disorder is the lower back (Lee et al., 2006; Schaub et al., 2007).

A limited number of study focus on psychosocial workload (defined as the peceptions or beliefs that workers have about the way their work environment is organized and referred to as work organizational factors or job stressor; Karasek, 1985; Karasek, Brisson, \& Kawakami, 1998; Buckle \& Devereux, 2002). As far as acknowledge by authors, only Lee et al. (2008), Wahlstedt et al. (2010), and Warner (2011) has reported work-related psychosocial load experienced by flight attendants. Lee stated that the work-related psychosocial load increase job strain of flight attendants and influence change in performance of job tasks.

It should be underlined, however, that flight attendants also have to perform mentally demanding work such as safety and security check (Damos et al., 2013). Therefore mental workload of flight attendants is important to be observed as well. In addition, Federal Aviation Administration (FAA, 2007) also noted the importance of considering mental aspect of flight attendants in the management of fatigue of flight attendants.

Mental workload can be understood as general term to describe the mental cost of executing task requirements (Hart \& Wickens, 1990; Wickens, 1992). Mental workload is crucial in work system design since mental overload is associated with decreased performance, increased errors, and decreased of human' wellbeing (Johnson \& Widyanti, 2011). In particular when worker experience extensive mental workload with insufficient rest time, there arise health problems such as stress (Cinaz et al., 2013). In contrast, mental underload correlates with boredom (Johnson \& Widyanti, 2011). Therefore assessment and evaluation of mental workload is very important and has been recognized for decades (Jo, Myung, \& Yoon, 2012).

Assessment of mental workload can be conducted based on performance, objective, and subjective method. Performance can be measured by accuracy and reaction time. Objective evaluation can be conducted through physiological indices such as heart rate variability (Widyanti et al., 2013, eye blink rate (Widyanti et al., 2017) and skin conductance (Widyanti et al., 2017b). The objective measures give advantages as it require a relatively small number of samples and can provide accurate result. However, the disadvantages of this objective method is that they are requiring special technical skill and operational experience (Lean \& Shan, 2012). In contrast, subjective measures of mental workload are inexpensive and easily administered. However, this measures are unable to provide precise reports and often require a large number of samples (Lean \& Shan, 2012). The most widely employed subjective rating scales are the subjective workload assessment technique (SWAT) and the NASA-TLX (Dey \& Mann, 2010).

The NASA-TLX is a multidimensional scale consist of six subscales: mental demand (defined as how much mental and perceptual activity was required e.g. thinking, deciding, calculating, remembering, looking, searching, etc? Was the task easy or demanding, simple or complex, exacting or forgiving?), physical demand (defined as how much physical activity was required e.g. pushing, pulling, turning, controlling, activating, etc? Was the task easy or demanding, slow or brisk, slack or strenuous, restful or loborious?), temporal demand (defined as how much time pressure did you feel due to the rate or pace at which the tasks or task elements occured? Was the pace slow and leisurely or rapid and frantic?), performance (defined as how succesful do you think you were in accomplishing the goals of the task set by experimenter or yourself? How satisfied were you with your performance in accomplishing these goals?), effort (defined as how hard did you have to work mentally and physically to accomplish your level of performance?), and frustration level (defined as how insecure, discourage, irritated, stressed, and annoyed versus secure, gratified, content, relaxed, and complacent did you feel during the task?). Participants was asked to give rating on each subscale ranging from $0-100$. Final score was obtained by averaging the score of the six subscales.

The aim of the study is therefore to observe mental workload of flight attendants. Yet, research on this areas is lacking. It should be noted that the airline in all over the world has increased in a very significant number, calling an urgent need of assessment of the workload of flight attendant to ensure the service quality of flight attendants, which in the end also influence the safety of the airline. It is expected by evaluating the existing workload, rearrange of workload can be conducted to provide optimal workload, in particular optimal mental workload for the flight attendants.

\section{Method}

\subsection{Participants}

The study population is flight attendants of the biggest Indonesian airline. Two hundred and one flight attendants (mean age $=24.6$ years, $\mathrm{SD}=3.8$ years, all female) participate voluntarily in this study. Average work time of the participants was 3.5 year. Permit is obtained from human resources management of the airline for data collection. Participants are recruited based on convenience sampling due to restricted work hours of data collection. Flight attendants that have been finished their flight duty are obligated to come to Human Resource Management office for reporting their finished flight. After the reporting process, the questionnaire is requested to be filling out by the flight attendants. Overall, 5 minutes is needed to complete the questionnaire.

\subsection{Instruments}

An open question about factors that influence flight attendants' performance and need to be improved is given to the participants as well as the Indonesian version of the raw NASA-TLX (Hart \& Staveland, 1988; Johnson \& Widyanti, 2011; Widyanti et al., 2013; Widyanti, Johnson, \& de Waard, 2013 that is used to measure mental workload of flight attendants. 


\section{Result and analysis}

Demographic data of the respondents can be seen in Table 1 .

Table 1. Demographic data of the respondents

\begin{tabular}{|l|l|ll|}
\hline \multicolumn{2}{|c|}{ Demographic factors } & \multicolumn{2}{c|}{ Number (percentage) } \\
\hline Age & $\begin{array}{l}\text { Less than 24.6 } \\
\text { years } \\
\text { Equal or more } \\
\text { than 24.6 years }\end{array}$ & 105 & $(52.2 \%)$ \\
\hline Work experience & $\begin{array}{l}\text { Less than 3.5 } \\
\text { years } \\
\text { Equal or more } \\
\text { than 3.5 years }\end{array}$ & 75 & $(47.8 \%)$ \\
\hline
\end{tabular}

Factors that are stated to influence performance of flight attendants and needs to be improved can be seen in Table 2.

Table 2. Factors that are complaining by the flight attendants

\begin{tabular}{|l|c|}
\hline \multicolumn{1}{|c|}{ Factors } & \multicolumn{1}{|c|}{$\begin{array}{c}\text { Number of } \\
\text { complaints }\end{array}$} \\
\hline Duration of rest period & 136 \\
\hline Jet lag & 95 \\
\hline Scheduling & 94 \\
\hline Duration of work & 94 \\
\hline $\begin{array}{l}\text { Management (example: salary, } \\
\text { management support, etc) }\end{array}$ & 94 \\
\hline Other (health problems, family time) & 5 \\
\hline
\end{tabular}

Mean and standard deviation of mental workload of Indonesian flight attendants measured using the NASATLX is 76. 08 (SD = 12.66) out of 100 . The score for each dimension of the NASA-TLX can be seen in Figure 1.

Additional analysis is applied to observe mental workload based on demographic data of the respondents. Based on category of age and work experience, no significant differences are found in mental workload of the flight attendants.

Since mental workload is related to time or temporal demand, coupled with the fact that the most complaints of the flight attendants in this study is related with scheduling as well as work and rest duration, further analysis of mental workload based on the flight duration is con-
Table 3. Flight category based on flight duration and the corresponding number of participants

\begin{tabular}{|l|c|c|}
\hline Flight category & $\begin{array}{c}\text { Flight duration, } \\
\text { hour(s) }\end{array}$ & $\begin{array}{c}\text { Number or } \\
\text { participants }\end{array}$ \\
\hline Extra short & $<1$ & 22 \\
\hline Short & $1-2$ & 61 \\
\hline Medium & $2-3$ & 55 \\
\hline Extra medium & $3-8$ & 28 \\
\hline Long & $>8$ & 35 \\
\hline
\end{tabular}

ducted. The categorization of the flight duration is based on Standard Operation Procedure SOP of the airline that can be seen in Table 3 .

ANOVA reveals no significant differences in mental work load based on flight duration, as well as no significant differences in all dimensions of the NASA-TLX, except for the temporal demand. As can be seen in Figure 2, there is a slightly difference between mental workload in extra short and short duration $(\mathrm{F}=6.05, \rho=0.05, \mathrm{MSE}=$ 3.14 ), in which mental workload is lowest during short flight and highest during extras short duration.

In addition, Figure 3 shows the NASA-TLX dimensions based on flight duration category. For all dimensions of the NASA-TLX, significant differences are found in physical demand $(\mathrm{F}=8.36, \rho<0.05, \mathrm{MSE}=4.10)$, temporal demand $(\mathrm{F}=13.88, \rho<0.05$, MSE $=4.97)$, and effort $(\mathrm{F}=7.09, \rho<0.05, \mathrm{MSE}=3.48)$.

\section{Discussion}

This study is aimed to observe mental work load of Indonesian flight attendants. Results show that the average mental workload of the flight attendants regardless the flight duration, measured using the NASA-TLX, is 76. 08 $(\mathrm{SD}=12.66)$ out of 100 . The score indicates a medium level of mental workload. This result is not surprising, since Damos et al. (2013) and Schaub et al. (2007) already state that flight attendants has also to perform mentally demanding task such as safety and security check, instead of passenger service only. In addition, Federal Aviation Administration (FAA) also underlined the issue of fatigue of flight attendant, which caused by not only physical, but also mental demanding task of flight attendants.

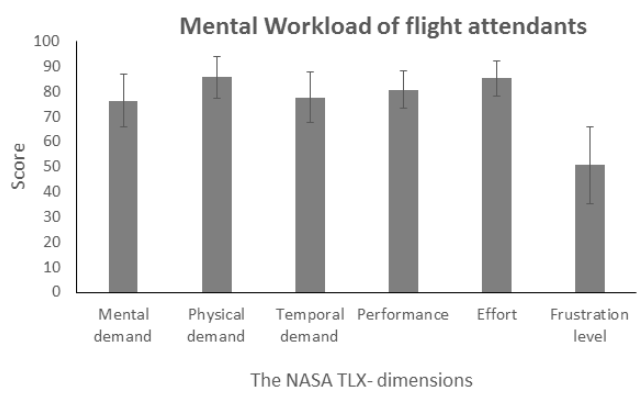

Figure 1. Mental workload of flight attendants

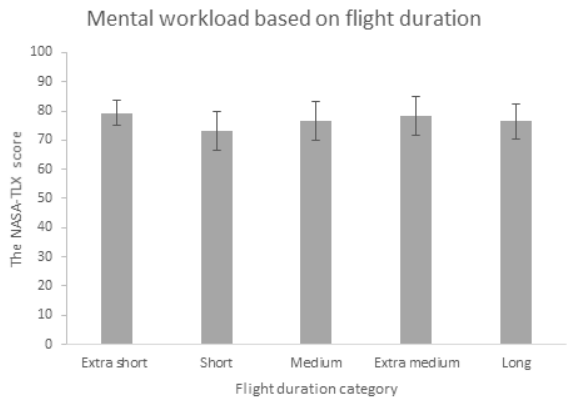

Figure 2. Mental workload on flight duration 


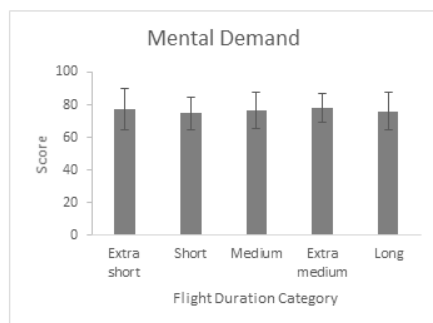

(a)

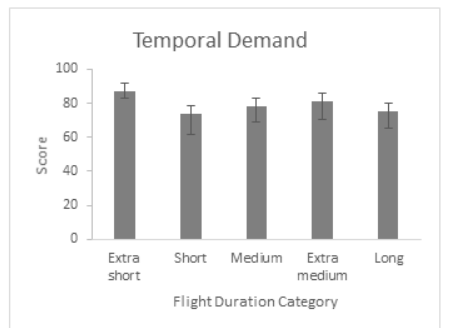

(c)

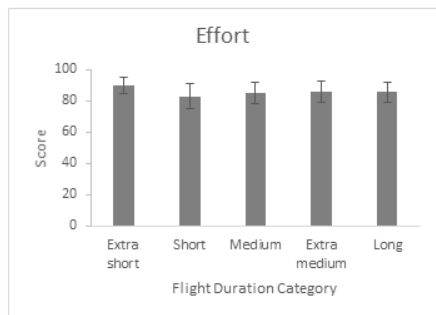

(e)

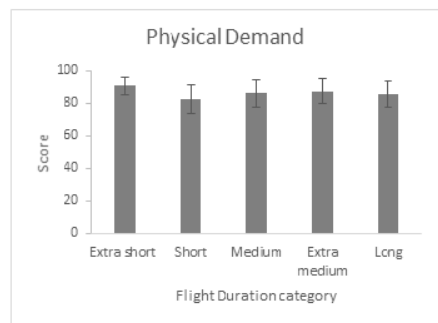

(b)

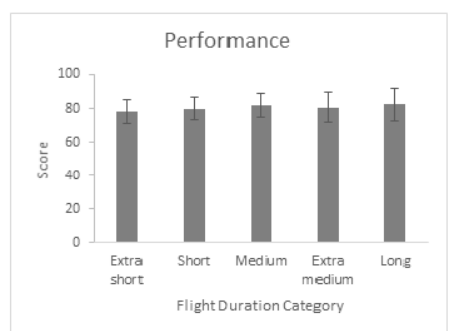

(d)

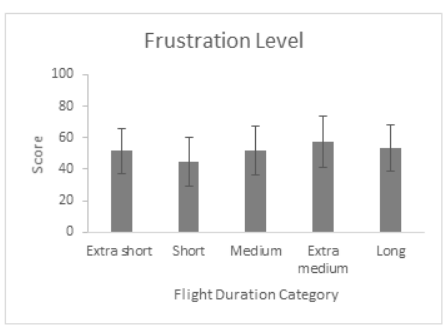

(f)

Figure 3. Mental workload of flight attendants

Demographic condition of the respondents in term of age and work experience do not influence the mental workload of the flight attendants. Considering that mental workload is involve two conditions that are task demand and capacity/capability of the worker, this present study gives valuable result about the source of mental demand among flight attendants, in which the task demand plays a more important role in the mental workload than the worker condition or capability. This result is in line with result of previous study by Pérusse-Lachance et al. (2012) who stated that demographic condition of respondents (i.e, gender differences) did not affect the physiological response induced by the cognitive demand of similar mental tasks.

The NASA-TLX is used in this study with the reason of practicability, since objective measure of mental workload using Electroencephalograph (EEG), eye tracker, and heart rate variability are not possible to be conducted in real work system of flight attendants due to its intrusiveness. Whereas other subjective method of mental workload measures such as Subjective Workload Assessment Technique (SWAT) needs particular procedure that cannot be applied in flight attendants' work setting.

Breaking down the NASA-TX based on the dimensions or the source of mental workload, the highest scores of the NASA-TLX dimensions in this study are physical demand, effort, and performance. This result of high physical demand is in line with studies conducted by Lee et al. (2006), Glitsch et al. (2007), Han (2003), Jager et al. (2007), and Schaub et al. (2007) who reviewed physically strenuous activities of flight attendants such as handling carry-on baggage and service to passengers. The high value of dimension effort in the NASA-TL needed by the flight attendants are therefore as the consequences of the demanding task. Last, the high score of the NASA-TLX' performance is related to the requirement of high performance and service quality of the flight attendants, which in the end influence the quality of the airline (Park et al., 2004).

In depth-analysis of the mental workload based on the flight duration shows that optimal duration flight based on mental workload point of view is the short category of flight duration that is 1 hour-2 hours. Whereas the most mentally demanding light duration is the extras short flight duration. Additional interview to the flight attendants and airline management reveals that for extra short flight duration, flight attendants have very tight and mentally demanding schedule (several extra flight duration for a day). Flight duration 1 hour-2 hours shows lower mental workload due it appropriate transit schedule so that flight attendants can take enough rest during the transit time.

This study is a first study in the mental workload of flight attendants, in which the kind of study is particularly important in providing optimal workload to enhance 
performance as well as safety and health of flight attendants. Since literature of mental workload measures of flight attendants is absent, the present study gives valuable contributions in providing a picture of mental workload of flight attendants and optimal mental workload analysis based on flight duration category. Although there was no study that directly quantify mental workload of flight attendants, the result of this study is supporting the result of previous studies conducted by Feijo, Luis, and Camara (2014), Ballard et al. (2006), and Heuven and Bakker (2003) who found mental disorder among flight attendants as the consequences of excessive mental workload. Final report of FAA (2007) also underlined the importance of issue of mental workload and mental fatigue among flight attendants.

This study has several limitations worth noting. First, caution is called for in generalizing the findings. The sample of the Indonesian flight attendants is only limited for one airline. Therefore, generalizability is limited. Second, the participants of this study are limited to female flight attendants due to its naturall work of flight attendants that are dominated by female workers. Further research involves male flight attendants may enrich the result and the analysis. Third, analyze of the mental workload based on flight duration is designed as between subject study due to difficulty to match every flight attendants to every possible flight duration. Further research with a design of within subject comparison will enrich the analysis.

The result of this study is valuable in giving a picture of mental workload among flight attendants. Airline industries should find ways to obtain and maintain work load of flight attendants that are safe and comfort, which in the end making the flight attendants to be motivated to perform the job and deliver service perfectly. Such way is for example rearrange flight schedule that give optimal mental workload. As stated by Vatankhah, Javid, and Raoofi (2017), airline industries must provide organizational support for the best performance of flight attendants.

\section{Conclusions}

In conclusion, the task performed by Indonesian flight attendants can be classified as hazardous as it gives medium - almost high - mental workload, beside high physical workload and musculoskeletal symptoms. In particular for the relation of mental workload and flight duration, it can be concluded that the optimal duration of a flight is 1-2 hours. However, further research to explore this would be valuable in particular in the context of flight duration and other factors than mental workload.

\section{Acknowledgements}

Authors thank to all the flight attendants' respondents for their participations in this study.

\section{Funding}

There is no funding for this study.

\section{Author contributions}

AW and MF conceived the study and were responsible for the design and development of the data collection and analysis. AW wrote the article and responsible for the submission process.

\section{Disclosure statement}

Authors declare there are no competing financial, professional, or personal interests from other parties.

\section{References}

Ballard, T. J., Romito, P., Lauria, L., Vigiliano, V., Caldora, M., Mazzanti, C., \& Verdecchia, A. (2006). Self-perceived health and mental health among women flight attendants. Occupational Environment Medicine, 63(1), 33-38.

https://doi.org/10.1136/oem.2004.018812

Buckle, P. W., \& Devereux J. J. (2002). The nature of work-related neck and upper limb musculoskeletal disorders. Applied Ergonomics, 33(3), 207-217. https://doi.org/10.1016/S00036870(02)00014-5

Chen, C., \& Kao, Y. (2011). The antecedents and consequences of job stress of flight attendants e evidence from Taiwan. Journal of Air Transport Management, 17(4), 253-255.

https://doi.org/10.1016/j.jairtraman.2011.01.002

Chen, T. H, Wu, K. H, Lin, W. J., Horna, W. I., \& Shieh, C. J. (2010). Incorporating workload and performance levels into work situation analysis of employees with application to a Taiwanese hotel chain. American Journal of Applied Sciences, 7(5), 692-697. https://doi.org/10.3844/ajassp.2010.692.697

Cinaz, B., Arnrich, B., La Marca, R., \& Tröster, G. (2013). Monitoring of mental workload levels during an everyday life office-work scenario. Personal and ubiquitous computing, 17(2), 229-239. https://doi.org/10.1007/s00779-011-0466-1

Cohen, A. I., Gjessing, C. C., Fine, I. J., Bernard, B. P. \& McGlothin, J. D. (1997). Elements of ergonomics programs: A primer based on workplace evaluations of musculoskeletal disorders. National Institute for Occupational Safety and Health. Cincinnati.

Damos, D. L., Boyett, K. S. \& Gibbs, P. (2013). Safety versus passenger service: The flight attendants' dilemma. The International Journal of Aviation Psychology, 23(2), 91-112. https://doi.org/10.1080/10508414.2013.772822

Davidson, M., Guilding, C., \& Timo, N. (2006). Employment, flexibility and labor market practices of domestic and MNC chain luxury hotels in Australia: Where has accountability gone? Internal Journal Hospitality Management, 25(2), 193210. https://doi.org/10.1016/j.ijhm.2005.08.001

Dey, A., \& Mann, D. D. (2010). Sensitivity and diagnosticity of NASA-TLX and simplified swat to assess the mental workload associated with operating an agricultural sprayer. Ergonomics, 53(7), 848-857. https://doi.org/10.1080/00140139.2010.489960

Federal Aviation Administration (FAA). (2007). Flight attendants fatigue. Final report. 
Feijo, D., Luiz, R. R., \& Camara, V. M. (2014). Common mental disorders among civil aviation flight attendants. Aviation Space Environment Medicine, 85(4), 433-439.

https://doi.org/10.3357/ASEM.3768.2014

Glitsch, U., Ottersbach, H. J., Ellegast, R., Schaub, K., Franz, G., \& Jager, M. (2007). Physical workload of flight attendants when pushing and pulling trolleys abroad aircraft. International Journal of Industrial Ergonomics, 37(11-12), 845-854. https://doi.org/10.1016/j.ergon.2007.07.004

Gopher, D. \& Donchin, E. (1986). Workload - an examination of the concept. In K. R. Boff, L. Kaufman, \& J. P. Thomas (Eds.), Handbook of perception and human performance, 2, 41-1-41-49. New York: Wiley.

Griffiths, R. F., \& Powell, D. M. C. (2012). The occupational health and safety of flight attendants. Aviation Space Environmental Medicine, 83(5), 514-521.

https://doi.org/10.3357/ASEM.3186.2012

Han, H. M. (2003). Development of low back pain prevention program for civil airline flight attendants (Dissertation). Yonsei University. Seoul, Korea.

Hart, S. G., \& Staveland, L. E. (1988). Development of NASATLX (Task Load Index): results of empirical and theoretical research. In P. A. Hancock, N. Meshkati (Eds.), Human mental workload (pp. 139-183). Elsevier, New York. https://doi.org/10.1016/S0166-4115(08)62386-9

Hart, S. G., \& Wickens, C. D. (1990). Workload assessment and prediction (pp. 257-296). Manprint. Springer. https://doi.org/10.1007/978-94-009-0437-8_9

Heuven, E., \& Bakker, A. B. (2003). Emotional dissonance and burnout among cabin attendants. European Journal of Work and Organizational Psychology, 12(1), 81-100. https://doi.org/10.1080/13594320344000039

Hsu, Y.-L., \& Liu, T. C. (2012). Structuring risk factors related to airline cabin safety. Journal of Air Transport Management, 20, 54-56. https://doi.org/10.1016/j.jairtraman.2011.12.009

Jager, M., Swatzki, K., Glitsch, U., Ellegast, R., Ottersbach, J., Schaub, K., Franz, G., \& Luttmann, A. (2007). Load on the lumbar spine of flight attendants during pushing and pulling trolleys abroad aircraft. International Journal of Industrial Ergonomics, 37(11-12), 863-876.

https://doi.org/10.1016/j.ergon.2007.07.010

Jo, S., Myung, R. \& Yoon, D. (2012). Quantitative prediction of mental workload with the ACT-R cognitive architecture. International Journal of Industrial Ergonomics, 42(4), 359-370. https://doi.org/10.1016/j.ergon.2012.03.004

Johnson, A., \& Widyanti, A. (2011). Cultural influences on the measurement of mental workload. Ergonomics, 54(6), 509518. https://doi.org/10.1080/00140139.2011.570459

Karasek, R. (1985). Job content instrument questionnaire and user's guide, version 1.1. Department of Industrial and Systems Engineering. University of Southern California. Los Angeles. https://doi.org/10.1037/t03609-000

Karasek, R., Brisson, C., \& Kawakami, N. (1998). The job content questionnaire (JCQ): An instrument for internationnaly comparative assessments of psychosocial job characteristics. Journal of Occupational Health Psychology, 3(4), 322-355. https://doi.org/10.1037/1076-8998.3.4.322

Karatepe, O. M., \& Talebzadeh, N. (2016). An empirical investigation of psychological capital among flight attendants. Journal of Air Transport Management, 55, 193-202.

https://doi.org/10.1016/j.jairtraman.2016.06.001

Lean, Y., \& Shan, F. (2012). Brief review on physiological and biochemical evaluations of human mental Workload. Human
Factors and Ergonomics in Manufacturing \& Service Industries, 22(3), 177-187. https://doi.org/10.1002/hfm.20269

Lee, H., Wilbur J., Kim, M. J., \& Miller, A. M. (2008). Psychosocial risk factors for work-related musculoskeletal disorders of the lower-back along long-haul international female flight attendants. Journal of Advanced Nursing, 61(5), 492-502. https://doi.org/10.1111/j.1365-2648.2007.04511.x

Lee, H., Wilbur, J., Conrad, K. M., \& Miller, A. M. (2006). Risk factors associated with work-related musculoskeletal disorders among female flight attendants. Using a focus group to prepae a survey. Workplace Health \& Safety, 54(4), 154-164. https://doi.org/10.1177/216507990605400405

Mellert, V., Baumann, I., Freese, N., \& Weber, R. (2008). Impact of sound and vibration on health, travel comfort, and performance of flight attendants and pilots. Aerospace Science and Technology, 12(1), 18-25.

https://doi.org/10.1016/j.ast.2007.10.009

Nagda, N. L., \& Koonts, M. D. (2003). Review of studies on flight attendant health and comfort in airliner cabins. Aviation Space Environment Medicine, 74(2), 101-109.

Nyberg, M., \& Lennernäs, W. M. (2017). Impossible meals? The food and meal situation of flight attendants in Scandinavia A qualitative interview study. Appetite, 113, 162-171. https://doi.org/10.1016/j.appet.2017.02.033

Park, J., Robertson, R., \& Wu, C. (2004). The effect of airline service quality on passengers' behavioral intentions: a Korean case study. Journal of Air Transport Management, 10(6), 435439. https://doi.org/10.1016/j.jairtraman.2004.06.001

Pérusse-Lachance, E., Tremblay, A., Chaput, J. P., Poirier, P., Teasdale, N., Drapeau, V., Sénécal, C., \& Brassard, P. (2102). Mental work stimulates cardiovascular responses through a reduction in cardiac parasympathetic modulation in men and women. Bioenergetics, 2(1), 1-6.

Ratanakomut, S., \& Kitcharoen, N. (2013). A study of factors that affecting service quality of passenger service department airlines (Air Asia, Thailand). Innovative Journal of Business and Management, 2(1), 9-18. http://innovativejournal.in/index. php/ijbm/article/view/400

Schaub, K., Berg, K., Winter, G., Ellegast, R., Glitsch, U., Jurgen, O., Jager, M., \& Franz, G. (2007). Muscular capabilities and workload of flight attendants for pushing and pulling trolleys abroad aircraft. International Journal of Industrial Ergonomics, 37(11-12), 883-892. https://doi.org/10.1016/j.ergon.2007.07.002

Vatankhah, S., Javid, E., \& Raoofi, A. (2017). Perceived organizational support as the mediator of the relationships between high-performance work practices and counter-productive work behavior: Evidence from airline industry. Journal of Air Transport Management, 59, 107-115.

https://doi.org/10.1016/j.jairtraman.2016.12.001

Wahlstedt, K., Lindgren, T., Norbäck, D., Wieslander, G., \& Runeson, R. (2010). Psychosocial work environment and medical symptoms among Swedish commercial airline cabin crew. American Journal of Industrial Medicine, 53, 716-723. https://doi.org/10.1002/ajim.20822

Warner, M. (2011). The role of social support on flight attendants performing emotion work and their work engagement. Thesis. University of Amsterdam.

Wickens, C. D. (1992). Virtual reality and education. Systems, Man and Cybernetics, IEEE International Conference on, 0992. IEEE (pp. 842-847). https://doi.org/10.1109/ICSMC.1992.271688

Widyanti, A., de Waard, D., Johnson, A., \& Mulder, B. (2013). National culture moderates the influence of mental effort on 
subjective and cardiovascular measure. Ergonomics, 56(2), 182-194. https://doi.org/10.1080/00140139.2012.748219

Widyanti, A., Hanna, Muslim, K., \& Sutalaksana, I. Z. (2017a). The sensitivity of Galvanic Skin Response for assessing mental workload in Indonesia. Work, 56(1), 111-117. https://doi.org/10.3233/WOR-162479

Widyanti, A., Johnson, A., \& de Waard, D. (2013). Adaptation of the Rating Scale Mental Effort (RSME) for use in Indonesia. International Journal of Industrial Ergonomics, 43(1), 70-76. https://doi.org/10.1016/j.ergon.2012.11.003
Widyanti, A., Sofiani, N. F., Soetisna, H. R., \& Muslim, K. (2017b). Eye blink rate as a measure of mental workload in a driving task: Convergent or divergent with other measures? International Journal of Technology, 8(2), 283-291. https://doi.org/10.14716/ijtech.v8i2.6145

Yeh, C-W. (2012). Relationships among service climate, psychological contract, work engagement and service performance. Journal of Air Transport Management, 25, 67-70. https://doi.org/10.1016/j.jairtraman.2012.08.011 